\title{
PENETAPAN BEA PEROLEHAN HAK ATAS TANAH DAN BANGUNAN DALAM PERALIHAN HAK ATAS TANAH DI KABUPATEN ASAHAN
}

\author{
(Tinjauan Yuridis Peraturan Daerah Kabupaten Asahan Nomor 3 Tahun \\ 2011 tentang Bea Perolehan Hak Atas Tanah dan Bangunan)
}

\author{
Bahmid
}

Fakultas Hukum Universitas Asahan

E-mail: bahmidpanjaitan@yahoo.co.id

\begin{abstract}
Tax is the largest contribution to the country as well as the implementaion of regionl autonomy. District or City expects tax as a large contribution to local revenue. One source of tax received by the state is Acquisition Duty of Right on Land and Building (Bea Hak Atas Tanah dan Bangunan (BPHTB)). Law Number 28 of 2009 concerning Regional Tax and Regional Retribution, Acquisition Duty of Right on Land and Building. Regional Regulation Number 3 of 2011 concerning Collection Procedure of Acquisition Cost. District Head Regulation Number 16 of 2011 concerning Acquisition Duty of Right on Land and Building in Asahan. Taxable object of BPHTB is acquisition duty of right on land and building. In Application, to knowing and explaining even giving evaluation how to calculate the cost of acquisition duty of right on land and building based on Regional Regulation of Asahan Number 3 of 2011 concerning Acquisition Duty of Right on Land and Building.
\end{abstract}

\section{Kata Kunci: Bea, Hak Atas Tanah, Bangunan}

\section{A. Latar Belakang}

Setiap orang memerlukan kebutuhan hidup yang berbeda-beda, sehingga harus memiliki penghasilan agar dapat memenuhi dan membiayai semua kebutuhan hidup tersebut. Negara juga tidak jauh berbeda dengan keadaan di atas, karena negara juga memiliki kebutuhan serta membutuhkan biaya pembangunan semua sarana dan prasarana untuk kepentingan warga masyarakatnya. Sebagai upaya untuk memenuhi kebutuhan tersebut, negara melalui pemerintah sebagai penyelenggara pemerintahan memperoleh kebutuhan tersebut ada yang berasal dari dalam negeri dan ada yang dari luar negeri. Sumber dana yang berasal dari luar negeri biasanya merupakan dana pelengkap, baik berupa penanaman modal 
asing maupun berupa pinjaman yang dilakukan secara bilateral atau multilateral. Sumber dana dari dalam negeri dapat berasal dari tabungan masyarakat, tabungan pemerintah atau dari pajak yang dibayar oleh masyarakat sebagai salah satu sumber pemenuhan kebutuhan tersebut.

Pajak adalah iuran kepada negara (yang dapat dipaksakan), yang terhutang oleh yang wajib membayarnya menurut peraturan-peraturan dengan tidak mendapat prestasi kembali, yang langsung dapat ditunjuk, dan yang gunanya untuk membiayai pengeluaran-pengeluaran umum berhubungan dengan tugas Negara untuk menyelenggarakan pemerintahan (Brotodiharjo 2008: 6).

Pajak pada mulanya merupakan upeti atau pemberian secara cuma-cuma, namun sifatnya merupakan suatu kewajiban yang dapat dipaksakan yang harus dilaksanakan oleh masyarakat kepada seorang raja atau penguasa. Pada masa dahulu rakyat/masyarakat memberikan pajak atau upeti berupa benda natura seperti padi, ternak dan hasil tanam lainnya seperti pisang, kelapa dan sebagainya. Pemberian tersebut dilakukan karena kedudukan raja yang tinggi dalam struktur kemasyarakatan pada waktu itu (Ilyas \& Burton 2004: 3). Dalam perkembangannya sifat upeti tidak hanya diberikan untuk kepentingan raja/penguasa, tetapi sudah mengarah kepada kepentingan rakyat itu sendiri yaitu upeti yang diberikan digunakan sebagai alat untuk meminta perlindungan keamanan, maupun untuk melakukan kepentingan umum lainnya.

Pesatnya perkembangan dalam sistem kemasyarakatan apalagi setelah adanya pemisahan antara rumah tangga pribadi, rumah tangga raja dan rumah tangga negara atau dengan kata lain sudah mulai terbentuknya negara, upeti yang semula hanya untuk kepentingan raja mulai mendapat tempat sebagai pendapatan negara (Suandy 2002: 5). Seiring dengan perkembangan zaman, pajak telah menjadi primadona sebagai sektor yang memberikan penerimaan terbesar bagi negara, serta merupakan salah satu sumber dana utama dalam melakukan pembangunan termasuk di negara Indonesia tercinta ini.

Dengan keadaan ini memberikan arti bahwa kemandirian bangsa dan negara dalam pembiayaan pengeluaran negara yang menjadi tujuan dari reformasi perpajakan akan semakin nyata untuk terwujud, dan jika dibandingkan dengan 
keadaan pada pertengahan dekade tahun 70-an sampai dengan tahun 80-an, penerimaan negara dalam APBN masih dikuasai oleh penerimaan dari sektor minyak dan gas (Migas). Akhir tahun 80-an ketika potensi minyak mulai menurun, maka pajak muncul sebagai penerimaan negara yang besar dan menggantikan peran dari minyak dan gas (Migas). Secara implisit ini berarti bahwa peranan rakyat semakin besar dalam pelaksanaan pembangunan, sehingga seharusnya pemerintah pun lebih peduli dan lebih memperhatikan kepentingan rakyatnya baik dalam melaksanakan penerapan peraturan perpajakan juga terhadap penggunaannya (Ismawan 2000: 4).

Dasar hukum penerapan pemungutan pajak di Indonesia adalah ketentuan yang terdapat dalam Pasal 23 huruf A Undang Undang Dasar 1945 (Amandemen Ketiga) yang berbunyi: Pajak dan pungutan lain yang bersifat memaksa untuk keperluan negara diatur dengan undang-undang. Besarnya peran yang diberikan oleh pajak sebagai sumber dana dalam pembangunan nasional, maka tentunya perlu lebih digali lagi potensi pajak yang ada dalam masyarakat sesuai dengan situasi dan kondisi perekonomian serta perkembangan bangsa ini. Salah satu sumber potensi pajak yang patut digali sesuai situasi dan kondisi perekonomian, serta perkembangan pembangunan bangsa sekarang ini adalah jenis Pajak Bea Perolehan Hak Atas Tanah dan Bangunan (Siahaan 2003: 6).

Bea Perolehan Hak Atas Tanah dan Bangunan (selanjutnya disebut BPHTB), sebenarnya bukanlah hal yang baru dalam bidang perpajakan yang dipungut oleh pemerintah, karena pajak jenis ini telah pernah diberlakukan di Indonesia ketika masih di bawah penjajahan Belanda. Pajak jenis ini terhapus dengan berlakunya Undang-undang Nomor 5 Tahun 1960 tentang Pokok-pokok Agraria (UU No. 5 Tahun 1960), tetapi kemudian diberlakukan lagi sesuai dengan ketentuan yang berlaku dalam UUPA. Dasar hukum pemungutan atas Bea Perolehan Hak Atas Tanah dan Bangunan (BPHTB) adalah Undang-undang Nomor 21 Tahun 1997 tentang Pajak Bea Perolehan Hak Atas Tanah dan Bangunan (UU No. 21 Tahun 1997), yang dikeluarkan pada tanggal 29 Mei 1997.

Dalam memori penjelasan UU No. 21 Tahun 1997, disebutkan bahwa tanah sebagai bagian dari bumi yang merupakan karunia Tuhan Yang Maha Esa, 
serta memiliki fungsi sosial, disamping memenuhi kebutuhan dasar untuk papan dan lahan usaha, juga merupakan alat investasi yang sangat menguntungkan. Selain itu, bagi pihak yang memperoleh hak atas tanah dan bangunan, wajib menyetorkan kepada negara melalui pembayaran pajak, dalam hal ini BPHTB.

Pada awal UU No. 21 Tahun 1997, yang dikeluarkan pada tanggal 29 Mei 1997 ditetapkan mulai berlaku secara efektif pada tanggal 1 Januari 1998, tetapi pada tanggal 31 Desember 1997 pemberlakuan BPHTB yang semula direncanakan berlaku efektif pada tanggal 1 Januari 1998 ditangguhkan dengan dikeluarkannya Peraturan Pemerintah Pengganti Undang-undang Nomor 1 Tahun 1997 tentang BPHTB ditangguhkan. Kemudian BPHTB belaku efektif pada tanggal 1 Juli 1998, sedangkan tujuan pembentukan undang-undang tentang BPHTB adalah perlunya diadakan pemungutan pajak atas Perolehan Hak Atas Tanah dan Bangunan, sebagaimana telah pernah dilaksanakan dan dilakukan sebagai, upaya kemandirian bangsa untuk memenuhi pengeluaran pemerintah berkaitan dengan tugasnya dalam menyelenggarakan pemerintahan umum dan pembangunan (Siahaan 2003: 44).

Dalam perkembangannya sesuai juga dengan perubahan yang terjadi dalam kehidupan dan perekonomian bangsa Indonesia, maka pada tahun 2000, dilakukan penyempurnaan terhadap UU No. 21 Tahun 1997 dengan dikeluarkannya Undang-undang Nomor 20 Tahun 2000 tentang perubahan atas Undangundang Nomor 21 Tahun 1997. Selanjutnya pada tahun 2009, lahirlah Undangundang No. 28 Tahun 2009 tentang Undang-undang Pajak Daerah dan Retribusi Daerah, Bea Perolehan Hak Atas Tanah dan Bangunan (UU No. 28 Tahun 2009), salah satu hal pokok yang mendasar adalah diserahkannya kewenangan pemungutan BPHTB kepada Pemerintah Daerah Kabupaten/Kota, sebagaimana diatur dalam Pasal 2 ayat 2 huruf $\mathrm{k}$.

Menyikapi lahirnya UU No. 28 Tahun 2009, Pemerintah Daerah Kabupaten Asahan dan DPRD Kabupaten Asahan telah melahirkan Peraturan Daerah Nomor 3 Tahun 2011 tentang Bea Perolehan Hak Atas Tanah dan Bangunann (Perda Kabupaten Asahan No. 3 Tahun 2011), sebagai payung hukum Pemerintah Daerah untuk melakukan pemungutan Bea Perolehan Hak atas Tanah 
dan Bangunan, peraturan daerah tersebut ditetapkan di Kisaran pada tanggal 16 Maret 2011 dan telah dimasukkan dalam lembaran Daerah Kabupaten Asahan Tahun 2011 Nomor 3 dan berlaku efektif pada tanggal ditetapkan.

Sebagai pelaksana dari Perda Kabupaten Asahan No. 3 Tahun 2011, Bupati Asahan juga telah menerbitkan Peraturan Bupati Asahan Nomor 16 Tahun 2011 tentang Prosedur Pemungutan Bea Perolehan Hak Atas Tanah dan Bangunan di Kabupaten Asahan, dengan demikian peraturan peraturan Bupati Asahan ini merupakan pelaksana dari perintah Perda Kabupaten Asahan No. 3 Tahun 2011 yang lebih rinci mengatur sistem dan prosedur pemungutan BPHTB.

BPHTB merupakan salah satu pajak obyektif atau pajak kebendaan dimana pajak terutang didasarkan pertama-tama pada apa yang menjadi obyek pajak baru kemudian memperhatikan siapa yang menjadi subyek pajak (Siahaan 2003: 59). Pemungutan BPHTB dilakukan dengan cara self assessment, yaitu wajib pajak diberikan kepercayaan untuk menghitung sendiri, serta membayar sendiri pajak yang terutang dengan menggunakan Surat Setoran Pajak Daerah Bea Perolehan Hak Atas Tanah dan Bangunan (SSPD) BPHTB dan melaporkannya tanpa mendasarkan kepada adanya surat ketetapan pajak. Hal ini sesuai dengan ketentuan yang terdapat dalam Pasal 5 ayat (1) Peraturan Bupati Asahan No. 16 Tahun 2011.

Berdasarkan ketentuan Pasal 2 ayat (1) Perda Kabupaten Asahan No. 3 Tahun 2011, dijelaskan yang menjadi obyek pajak BPHTB adalah perolehan hak atas tanah dan atau bangunan. Wirawan B. Ilyas dan Richard Burton (2004: 90), mengatakan bahwa BPHTB adalah perolehan hak atas tanah dan atau bangunan yang dapat berupa tanah (termasuk tanaman di atasnya), tanah dan bangunan, atau bangunan. Perolehan hak atas tanah dan bangunan terjadi karena adanya peralihan hak yang meliputi peristiwa hukum dan perbuatan hukum yang terjadi antara orang atau badan hukum sebagai subyek hukum yang oleh undang-undang dan peraturan hukum yang berlaku diberikan kewenangan untuk memiliki hak atas tanah dan bangunan, dan menurut hukum peralihan hak terjadi karena dua hal, yaitu hak beralih dan hak dialihkan. 
Hak beralih adalah suatu peralihan hak atas tanah dan atau bangunan yang disebabkan oleh orang yang memiliki suatu hak atas tanah dan atau bangunan meninggal dunia, sehingga hak tersebut beralih secara langsung kepada ahli waris, atau dapat juga dikatakan peralihan hak terjadi dengan tidak sengaja melalui suatu perbuatan melainkan terjadi karena hukum, atau dapat juga dikatakan bahwa hak atas tanah dan atau bangunan beralih karena peristiwa hukum. Hak dialihkan adalah suatu peralihan hak atas tanah dan atau bangunan yang dilakukan dengan sengaja sehingga hak tersebut terlepas dari pemegangnya semula dan menjadi hak pihak lain, dengan kata lain peralihan hak terjadi melalui perbuatan hukum tertentu yang dapat berupa jual beli atau hibah, wasiat dan sebagainya (Siahaan 2003: 61).

Untuk menentukan apakah suatu perolehan hak atas tanah dan bangunan sebagai obyek pajak adalah, bahwa peralihan yang terjadi baik karena peristiwa hukum maupun perbuatan hukum, mengakibatkan terjadinya perolehan hak atas tanah dan bangunan oleh seseorang atau badan hukum secara permanen. Selain itu peralihan hak yang terjadi juga harus sesuai dan tunduk kepada ketentuan hukum yang berlaku di Indonesia, yaitu dilakukan dengan menggunakan akta autentik, oleh dan di hadapan pejabat yang berwenang. Selain peralihan hak, pemberian hak baru juga dikenakan BPHTB.

Dalam pelaksanaanya, BPHTB melibatkan banyak pihak yang terkait seperti: Kantor Pertanahan, Notaris, Pejabat Pembuat Akta Tanah (PPAT), Bank, Pemerintahan Daerah, Pengadilan termasuk lembaga-lembaga yang ada di bawahnya, selain itu peraturan-peraturan yang mendukung pelaksanaan BPHTB juga saling terkait antara satu dengan lainnya. Akibat saling keterkaitan tersebut, baik keterkaitan peraturan maupun lembaga-lembaganya, maka dalam praktiknya tidak jarang malah dapat menimbulkan masalah. Salah satu masalah ketidakpahaman masyarakat tentang bagaimana cara prosedur penagihan dan pembayaran BPHTB dan lembaga apa yang berwenang dalam mengutip uang yang bersumber dari BPHTB, dan dalam kaitannya dengan Perda Kabupaten Asahan No. 3 Tahun 2011 yang relatif baru, selain BPHTB merupakan salah satuh sumber Pendapatan Asli Daerah (PAD) Kabupaten Asahan, maka penulis tertarik untuk menelitinya lebih 
lanjut yang bertujuan untuk mengetahui dan menganalisis penerapan penetapan bea perolehan hak atas tanah dan bangunan dalam peralihan hak atas tanah berdasarkan Perda Kabupaten Asahan No. 3 Tahun 2011.

\section{B. Metode Penelitian}

Jenis penelitian ini adalah yuridis normatif dan bersifat deskriptif, maksudnya bahwa penelitian ini difokuskan untuk menganalis dan mendeskripsikan penerapan penetapan bea perolehan hak atas tanah dan bangunan dalam peralihan hak atas tanah berdasarkan Perda Kabupaten Asahan No. 3 Tahun 2011. Sumber data penelitian adalah data sekunder berupa bahan hukum primer dan bahan hukum sekunder, sedangkan metode pengumpulan data yang digunakan adalah studi dokumen. Data yang terkumpul, dianalisis dengan menggunakan tehnik analisis kualitatif.

\section{Hasil Penelitian dan Analisis}

\section{Tinjauan umum tentang pajak.}

Ada banyak definisi pajak yang diberikan oleh para sarjana, salah satu definisi menurut P.J.A. Adriani, sebagaimana dikutip Brotodiharjo (2008: 2) dikatakan bahwa:

Pajak adalah iuran kepada negara (yang dapat dipaksakan), yang terhutang oleh yang wajib membayarnya menurut peraturan-peraturan dengan tidak mendapat prestasi kembali, yang langsung dapat ditunjuk, dan yang gunanya untuk membiayai pengeluaran-pengeluaran umum berhubungan dengan tugas negara untuk menyelenggarakan pemerintahan.

Menurut Rochmat Soemitro, sebagaimana dikutip Handoko (2000: 3), dikatakan bahwa: "pajak adalah iuran rakyat kepada kas negara (peralihan kekayaan dari sektor partikulir ke sektor pemerintah) berdasarkan undang-undang (yang dapat dipaksakan) dengan tiada mendapat jasa timbal balik yang langsung dapat ditunjukkan dan yang digunakan untuk membiayai pengeluaran umum".

Berdasarkan defenisi yang dipaparkan di atas, maka menurut Soemitro (1979: 23-24), dikatakan bahwa unsur-unsur pajak, mencakup hal-hal sebagai berikut: 
a. Pajak adalah suatu iuran kepada negara (yang sifatnya wajib), artinya setiap orang yang mendapat penghasilan tertentu wajib menyerahkan sebagian penghasilan kekayaannya kepada negara dan hukumnya wajib, baik dalam bentuk badan hukum maupun perorangan.

b. Pajak dapat dipaksakan, artinya yang berhak memungut pajak hanya negara. Iuran tersebut berupa uang (bukan barang), dan jika wajib pajak tertentu tidak membayar pajaknya, baik kepada pemerintah daerah maupun pemerintah pusat, maka fiskus akan menerapkan sanksi-sanksi keras kepadanya, yaitu barang-barang wajib pajak akan disita, baik barang bergerak maupun barang tidak bergerak oleh juru sita dan setelah disita barang-barang tersebut akan dilelang yang hasilnya menjadi hak negara untuk membangun negara.

c. Berdasarkan undang-undang, artinya pajak dipungut berdasarkan kekuatan undang-undang, serta aturan pelaksanaannya. Pengaturan pajak tersebut tidak boleh berdasarkan peraturan yang berada di bawah undang- undang.

d. Tanpa imbalan (kontraprestasi), artinya setiap orang yang membayar pajak tidak mendapat kontraprestasi secara langsung dari pemerintah. Dalam pembayaran pajak tidak dapat ditunjukkan adanya kontraprestasi individual oleh pemerintah.

e. Untuk kepentingan masyarakat, artinya penerimaan pajak negara digunakan untuk hal-hal yang berhubungan dengan kesejahteraan masyarakat umum. Digunakan untuk membiayai rumah tangga negara, yakni pengeluaranpengeluaran yang bermanfaat bagi masyarakat luas.

Dalam negara yang berdasarkan atas hukum, tentunya mempunyai tujuan yang hendak ditegakan dalam melaksanakan kegiatan pemerintahnya yang berdasarkan hukum tersebut. Tujuan hukum tersebut menurut Aristoteles adalah membuat adanya keadilan. Menurut Soemitro (1979: 23-24), dikatakan bahwa tujuan hukum tersebut oleh para sarjana dijadikan juga sebagai tujuan hukum pajak yang harus ditempuh dengan mengusahakannya yang mana dalam pemungutan pajak harus diselenggarakan secara umum dan merata. Tujuan yang menjadi asas pemungutan pajak dinamainya: "The Four Maxim", yaitu:

a. Asas keadilan

Dari keterangan yang telah disebutkan di atas, dapat dilihat bahwa keadilan merupakan tujuan dari hukum pajak.

b. Asas yuridis

Seperti halnya asas keadilan, maka pada asas yuridis ini juga berasal dari asasasas yang dikemukakan oleh Adam Smith, yaitu asas certainty yang menekankan pentingnya kepastian mengenai pemungutan pajak, yaitu kepastian mengenai subyek pajak dan objek pajak, serta kepastian mengenai tata cara pemungutannya.

Dalam asas ini seperti juga halnya asas certainty, pemungutan pajaknya juga harus terdapat jaminan hukum yang memberikan perlindungan terhadap 
keadilan secara tegas, baik untuk warga maupun untuk negaranya. Salah satu bentuk jaminan tersebut adalah dengan menetapkan undang-undang untuk mengatur segala sesuatu yang berhubungan dengan pajak. Sebagai contoh dapat dilihat dalam Pasal 23 huruf A Undang Undang Dasar 1945, yang menegaskan, bahwa pemungutan pajak untuk keperluan negara harus dilaksanakan berdasarkan undang-undang. Sehingga dengan adanya jaminan dalam bentuk undang-undang untuk mengatur setiap orang tidak merasa dirinya ragu untuk menjalankan kewajibannya untuk membayar pajak karena segala sesuatunya telah diatur secara jelas. Apabila si wajib pajak merasa berkeberatan atas jumlah pajak yang harus dibayar, maka oleh Undangundang Nomor 28 Tahun 2007 tentang Perubahan Ketiga atas Undang-undang Nomor 6 Tahun 1983 tentang Ketentuan Umum dan Tata Cara Perpajakan, dimungkinkan dilakukannya pengaduan ketidakpuasan tersebut kepada pihak atasan yang berwenang mengenai penetapan pajaknya yang dirasakan kurang adil.

c. Asas ekonomis

Dalam pemungutan pajak selain mempunyai fungsi budgeter, pajak juga berfungsi sebagai alat untuk menentukan politik perekonomian. Untuk itu dalam pelaksanaannya diharapkan tidak mengganggu kehidupan ekonomis dari wajib pajak.

d. Asas finansial

Pada asas terakhir ini dimaksudkan bahwa dalam pemungutan dan pengenaan pajak diusahakan menggunakan biaya yang sekecil dan sehemat mungkin dan mencukupi untuk pengeluaran.

Hukum pajak dapat dibedakan dalam 2 (dua) jenis, yaitu: (1) hukum pajak materil; dan (2) hukum pajak formil. Hukum pajak materil membuat aturan atau norma yang menerangkan suatu keadaan, perbuatan-perbuatan dan atau peristiwa hukum yang harus dikenakan pajak, siapa-siapa yang dikenakan sebagai wajib pajak, berapa jumlah hutang pajak, artinya segala sesuatu yang timbul terhadap akibat dari pembayaran pajak tersebut, termasuk besaran dan hapusnya utang pajak dan hubungan hukum anatara fiskus dan wajib pajak. Juga yang betalian dengan peraturan-peratuan yang memuat segala bentuk kenaikan-kenaikan, denda-denda dan hukuman-hukuman serta cara-cara tentang pembebasanpembebasan dan pengembalian pajak, serta memberikan kewenangan bagi fiskus untuk memberikan hak tagih utama kepada fiskus dan sebagainya diliputinya (Brotodiharjo 2008: 44-45). Hak tagih utama seperti wajib pajak mengalami pailit atau objek pajak dilelang, maka fiskus mempunyai hak utama mendapatkan penyelesaian hutang wajib pajak. 
Hukum pajak materil ini dalam kenyataannya segala aturan produk hukum seperti undang-undang, peraturan pemerintah, peraturan daerah yang memuat segala aturan mengenai aturan mengenai aturan yang menentukan subjek dan objek pajak, besaran jumlah pajak terhutang, upaya-upaya hukum yang dapat dilakukan wajib pajak apa bila terjadi sengketa pajak dan sanksi-sanksi pidana yang diancamkan kepada wajib pajak, fiskus atau bahkan pihak ketiga (seperti konsultan, notaris, PPAT) yang mempunyai kaitan khusus dengan wajib pajak dan fiskus.

Hukum materil pajak merupakan suatu aturan bagi orang/badan hukum untuk bertindak dan memahami hak dan kewajibannya sebagai objek dan atau subjek pajak. Dengan adanya hukum materil tersebut sehingga terukur hak dan kewajiban wajib pajak maupun fiskus, contoh dalam BPHTB wajib pajak dapat menghitung besaran pajak terhutang dari uraian-uraian ketentuan undang-undang atau peraturan daerah, yang memuat bagaimana wajib pajak tersebut dapat dibebankan hutang pajak.

Hukum pajak formil adalah peraturan-peraturan mengenai cara-cara untuk menjelmakan hukum materil tersebut di atas menjadi suatu kenyataan. Bagian hukum ini memuat cara-cara penyelenggaraan mengenai penetapan suatu utang pajak, kontrol oleh pemerintah terhadap penyelenggaranya, kewajiban para wajib pajak (sebelum dan sesudah menerima surat ketetapan pajak), kewajiban pihak ketiga, dan prosedur dalam pemungutanya. Maksud hukum formil adalah untuk melindungi, baik fiskus maupun wajib pajak. Jadi untuk memberi jaminan bahwa hukum materilnya akan dapat diselenggarakan setepat-tepatnya. Peraturanperaturan yang ditujukan untuk meneliti apakah ada kewajiban membayar pajak.

Dalam membicarakan hukum pajak materil yang telah disinggung di atas, bahwa misalnya dalam pajak pendapatan terdapat ketentuan-ketentuan bahwa seseorang baru dapat dikenakan pajak atas penghasilannya jika memenuhi syarat subjektif maupun syarat objektifnya. Fiskus baru bergerak setelah mengetahui dimana wajib pajak tinggal, apakah penghasilannya memenuhi syarat kena pajak, besarnya tanggungan keluarga, dan sebagainya. 
Pembedaan antara hukum pajak materil dan formil sangat penting, terutama harus dimengerti bahwa peraturan dari hukum formil tidak pernah akan menimbulkan suatu utang pajak, ini semata-mata ditentukan oleh hukum materil, tetapi adakalanya karena adanya peraturan-peraturan formil tertentu, maka suatu pajak yang telah ditentukan oleh peraturan materil, pemungutanya tidak mungkin diselenggarakan. Sebagai contoh menurut Brotodiharjo (2008: 72) adalah dalam hal tuntutan kemudian (navordering), yang tertuang pada Pasal 14d Ordinasi Pajak Pendapatan sebagai berikut:

a. Jika telah dikenakan ketetapan pajak yang kerendahan, atau diputuskan untuk tidak dikenakan pajak, pun bila ketetapan pajak yang telah dikenakan salah dikurangkan atau dibatalkan, maka pajak yang kurang pungut itu dapat ditagih kemudian, selama semenjak akhir tahun takwin tidak terlalu lewat tiga tahun.

b. Pajak yang termasuk ke dalam suatu ketetapan tagihan, kemudian ditambah seratus perseratus dari jumlah pajak itu, dan seterusnya.

Dengan terang disini dapat terlihat, bahwa dalam ayat (1) pada kalimat tambahan terakhir, terdapat suatu jangka waktu (3 tahun) sebagai suatu syarat formil tagihan yang kemudian ditagih. Dengan demikian walaupun menurut syarat materilnya seorang dapat dikenakan pajak yang lebih tinggi, tapi karena syarat formilnya tidak terpenuhi, sehingga pengenaan pajak yang sewajarnya tidak dapat dijalankan (Brotodiharjo 2008: 72).

Praktik pemungutan pada pajak pada umumnya mengenal sistem official assessment, self assessment, dan withholding. Sistem official assessment (official assessment system) adalah sistem pemungutan pajak yang memberi wewenang kepada pemerintah (fiskus) untuk menentukan besarnya pajak terutang. Adapun ciri-ciri dari official assessment system, yaitu: (a) wewenang untuk menentukan besarnya pajak terutang berada pada fiskus; (b) wajib pajak bersifat pasif; dan (c) utang pajak timbul setelah dikeluarkannya surat ketetapan pajak oleh fiskus. Negara yang menganut sistem pemungutan pajak ini adalah Belanda (Handoko 2000: 3). Kelemahan dari sistem pemungutan pajak ini adalah masyarakat kurang bertanggungjawab memikul beban negara yang pada hakikatnya adalah untuk kepentingan sendiri dalam hidup bermasyarakat, bernegara, dan berpemerintahan (Judisseno 1999: 24), dan hal ini terjadi karena wajib pajak bersifat pasif. 
Sistem self assessment (self assessment system) adalah sistem pemungutan pajak yang memberi wewenang, kepercayaan, tanggung jawab kepada wajib pajak untuk menghitung, memperhitungkan, membayar dan melaporkan sendiri besarnya pajak yang harus dibayar. Negara yang menganut sistem ini adalah Amerika Serikat, Jepang dan Indonesia (Handoko 2000: 32). Contohnya: pengenaan PPh dan BPHTB. Self assessment system adalah sistem pengenaan pajak yang memberi wewenang kepada wajib pajak untuk menentukan sendiri besarnya pajak yang terutang dengan ciri-ciri, bahwa: (a) wewenang untuk menentukan besarnya pajak terutang ada pada wajib pajak; (b) wajib pajak aktif, mulai dari menghitung, menyetor, melaporkan sendiri pajak yang terutang; dan fiscus tidak ikut campur dan hanya mengawasi.

Sistem withholding (withholding tax system) adalah sistem pemungutan pajak yang memberi wewenang kepada pihak ketiga untuk memotong atau memungut besarnya pajak yang terutang oleh Wajib Pajak. Pemotong pajak bisa majikan, bendahara atau pemberi kerja, disebut juga sistem Pay as You Earn (PYE) dan Pay as You Go (PYGO) yang artinya bayarlah pajak sebelum menerima gaji atau sebelum pergi (Handoko 2000: 32). Contohnya di Indonesia: pengenaan PPh berdasarkan Pasal 21 UU NO. 17 Tahun 2000, bahwa pajak penghasilan yang dikenakan atas penghasilan berupa gaji, upah, honorarium, tunjangan, dan pembayaran lain dengan nama apapun sehubungan dengan pekerjaan, jasa, atau kegiatan yang dilakukan oleh Wajib Pajak orang pribadi dalam negeri (Waluyo dan Ilyas 1999: 91).

\section{Deskripsi ringkas kabupaten Asahan}

Kabupaten Asahan adalah sebuah kabupaten yang terletak di Propinsi Sumatera Utara, yang terdiri dari 25 Kecamatan, 177 Desa, 27 Kelurahan, dan 1.538 Dusun/Lingkungan, dengan wilayah seluas $3.675 \mathrm{~km}^{2}$. Ibukota Kabupaten Asahan adalah Kisaran, yang berdasarkan Sensus 2010 mempunyai penduduk sebanyak 668.272 jiwa, sebagian besar adalah suku Melayu (75\%), sering juga disebut Melayu Asahan atau Melayu Batubara (https://id.wikipedia.org. diakses tanggal 25 Maret 2016). Mayoritas penduduk Kabupaten Asahan adalah beragama Islam, yaitu sebanyak 623.624 orang $(89.12 \%)$, diikuti dengan yang beragama 
Kristen sebanyak 64.063 orang (9.16\%), Budha sebanyak 7.187 orang (1.03\%), Katholik sebanyak 4.725 orang (0.68\%), Hindu sebanyak 113 (0.02\%), dan terkecil Khonghucu sebanyak 8 orang (0.01\%) (https://asahankab.bps.go.id. diakses tanggal 25 Maret 2016).

Jumlah Kecamatan di Kabupaten Asahan seperti tersebut di atas, dengan jumlah desa/kelurahan sebanyak 204 (177 desa +27 Kelurahan), dapat dilihat perinciannya sebagai berikut (https://asahankab.bps.go.id. diakses tanggal 25 Maret 2016):

1. Kecamatan Aek Kuasan, terdapat 7 desa/kelurahan, yaitu: Aek Loba, Aek Loba Afdeling I, Aek Loba Pekan, Alang Bombon (Bonbon), Lobbu Jior (Lobu Jiur), dan Rawa Sari Sengon Sari.

2. Kecamatan Aek Ledong, terdapat 7 desa/kelurahan, yaitu: Aek Bange, Aek Korsik, Aek Ledong, Aek Nabuntu, Ledong Barat, Ledong Timur, dan Padang Sipirok.

3. Kecamatan Aek Songsongan, terdapat 9 desa/kelurahan, yaitu: Aek Bamban, Aek Songsongan, Lobu Rappa, Marjanji Aceh, Mekar Marjanji, Perkebunan Bandar Pulau, Perkebunan Bandar Selamat, Situnjak dan Tangga.

4. Kecamatan Air Batu, terdapat 12 desa/kelurahan, yaitu: Air Genting, Air Teluk Hessa, Danau Sijabut, Hessa Air Genting, Hessa Perlompongan, Perkebunan Air Batu I-II, Perkebunan Air Batu III-IV, Perkebunan Pulahan, Pinanggiripan, Pulau Pule, Sei/Sungai Alim Ulu, dan Sijabut Teratai.

5. Kecamatan Air Jorman, terdapat 7 desa/kelurahan, yaitu: Air Joman, Air Joman Baru, Banjar, Binjai Serbangan, Pasar Lembu, Punggulan, dan Subur.

6. Kecamatan Bandar Pasir Mandoge, terdapat 9 desa/kelurahan, yaitu: Bandar Pasir Mandoge, Gotting Sidodadi, Huta Bagasan, Huta Padang, Sei Kopas, Sei Nadoras, Silau Jawa, Suka Makmur, dan Tomuan Holbung.

7. Kecamatan Bandar Pulau, terdapat 10 desa/kelurahan, yaitu: Aek Nagali, Bandar Pulau Pekan, Buntu Maraja, Gajah Sakti, Gonting Malaha, Gunung Berkat, Huta Rao, Padang Pulau, Perkebunan Aek Tarum, dan Perkebunan Padang Pulau

8. Kecamatan Buntu Pane, terdapat 9 desa/kelurahan, yaitu: Ambalutu, Buntu Pane, Karya Ambalutu, Lestari, Mekar Sari, Perkebunan Sei Silau, Prapat Janji, Sei Silau Timur, dan Sionggang

9. Kecamatan Kisaran Barat Kota, terdapat 13 desa/kelurahan, yaitu: Bunut, Bunut Barat, Dadi Mulyo, Sidodadi, Sei Renggas, Kisaran Barat, Kisaran Kota, Tebing Kisaran, Kisaran Baru, Mekar Baru, Sidomukti, Sendang Sari, dan Tegal Sari.

10. Kecamatan Kisaran Timur Kota, terdapat 12 desa/kelurahan, yaitu: Kisaran Naga, Gambir Baru, Lestari, Kisaran Timur, Teladan, Mutiara, Sentang, Siumbut-umbut, Siumbut Baru, Kedai Ledang, Selawan, dan Karang Anyer.

11. Kecamatan Meranti, terdapat 7 desa/kelurahan, yaitu: Air Putih, Gajah, Meranti, Perkebunan Sei Balai (Baleh), Sei Beluru, Serdang, dan Sukajadi. 
12. Kecamatan Pulau Rakyat, terdapat 12 desa/kelurahan, yaitu: Bangun, Baru, Manis, Mekar Sari, Ofa Padang Mahondang, Orika, Padang Mahondang, Persatuan, Pulau Rakyat Pekan, Pulau Rakyat Tua, Sei Piring, dan Tunggul Empat Lima.

13. Kecamatan Pulo Bandring, terdapat 10 desa/kelurahan, yaitu: Bunut Seberang, Gedangan, Perhutaan Silau, Pulo Bandring, Sidomulyo, Suka Damai, Suka Damai Barat, Suka Makmur, Taman Sari, dan Tanah Rakyat.

14. Kecamatan Rahuning, terdapat 7 desa/kelurahan, yaitu: Batu Anam, Gunung Melayu, Perkebunan Aek Nagaga, Perkebunan Gunung Melayu, Rahuning, Rahuning I, dan Rahuning II.

15. Kecamatan Rawang Panca Arga, terdapat 7 desa/kelurahan, yaitu: Panca Arga, Pondok Bungur, Rawang Baru, Rawang Lama, Rawang Pasar IV, Rawang Pasar V, dan Rawang Pasar VI.

16. Kecamatan Sei Dadap, terdapat 10 desa/kelurahan, yaitu: Bahung Sibatu-batu, Pasiran, Perkebunan Sei Dadap I-II, Perkebunan Sei Dadap III-IV, Sei Alim Hasak, Sei Kamah Baru, Sei Kamah I, Sei Kamah II, Tanjung Alam, dan Tanjung Asri.

17. Kecamatan Sei Kepayang, terdapat 6 desa/kelurahan, yaitu: Bangun Baru, Perbangunan, Pertahanan, Sei Kepayang Kanan, Sei Kepayang Tengah, dan Sei Paham.

18. Kecamatan Sei Kepayang Barat, terdapat 6 desa/kelurahan, yaitu: Sei Jawijawi, Sei Kepayang Kiri, Sei Lendir, Sei Nangka, Sei Serindan, dan Sei Tualang Pandau.

19. Kecamatan Sei Kepayang Timur, terdapat 5 desa/kelurahan, yaitu: Sarang Helang, Sei Lunang, Sei Pasir, Sei Sembilang, dan Sei Tempurung.

20. Kecamatan Setia Janji, terdapat 5 desa/kelurahan, yaitu: Bangun Sari, Sei Silau Barat, Sei Silau Tua, Silau Maraja, dan Urung Pane.

21. Kecamatan Silau Laut, terdapat 5 desa/kelurahan, yaitu: Bangun Sari, Lubuk Palas, Silo Baru, Silo Bonto, dan Silo Lama.

22. Kecamatan Simpang Empat, terdapat 8 desa/kelurahan, yaitu: Anjung Gadang, Perkebunan Hessa, Perkebunan Suka Raja, Sei Dua Hulu, Sei/Sungai Lama, Silomlom, Simpang Empat, dan Sipaku Area.

23. Kecamatan Tanjung Balai, terdapat 8 desa/kelurahan, yaitu: Asahan Mati, Bagan Asahan, Bagan Asahan Baru, Bagan Asahan Pekan, Kapias Batu VIII, Pematang Sungai/Sei Baru, Sei/Sungai Apung, dan Sei/Sungai Apung Jaya.

24. Kecamatan Teluk Dalam, terdapat 6 desa/kelurahan, yaitu: Air Teluk Kiri, Mekar Tanjung, Perkebunan Teluk Dalam, Pulau Maria, Pulau Tanjung, dan Teluk Dalam

25. Kecamatan Tinggi Raja, terdapat 7 desa/kelurahan, yaitu: Padang Sari, Piasa Ulu, Sidomulyo, Sumber Harapan, Teladan, Terusan Tengah, dan Tinggi Raja.

Berdasarkan data terakhir pada tahun 2014, jumlah penduduk Kabupaten Asahan sebanyak 699.720 jiwa, yang jumlah penduduknya pada masing-masing kecamatan dapat dilihat pada tabel berikut: 
Tabel 1:

\section{Banyaknya Penduduk Menurut Kecamatan dan Jenis Kelamin} Di Kabupaten Asahan Tahun 2014

\begin{tabular}{|r|l|r|r|r|}
\hline \multirow{2}{*}{ NO } & \multirow{2}{*}{ KECAMATAN } & \multicolumn{2}{|c|}{ JENIS KELAMIN } & \multirow{2}{*}{ JUMLAH } \\
\cline { 3 - 4 } & & LAKI-LAKI & PEREMPUAN & \\
\hline 1 & B. P. Mandoge & 17.631 & 16.762 & 34.393 \\
\hline 2 & Bandar Pulau & 10.961 & 10.462 & 21.423 \\
\hline 3 & Aek Songsongan & 8.677 & 8.558 & 17.235 \\
\hline 4 & Rahuning & 9.239 & 9.068 & 18.307 \\
\hline 5 & Pulau Rakyat & 16.582 & 16.467 & 33.049 \\
\hline 6 & Aek Kuasan & 12.037 & 11.832 & 23.869 \\
\hline 7 & Aek Ledong & 10.420 & 10.171 & 20.591 \\
\hline 8 & Sei Kepayang & 8.902 & 8.993 & 17.895 \\
\hline 9 & Sei Kepayang Barat & 6.757 & 6.639 & 13.396 \\
\hline 10 & Sei Kepayang Timur & 4.622 & 4.367 & 8.989 \\
\hline 11 & Tanjung Balai & 18.525 & 18.013 & 36.538 \\
\hline 12 & Simpang Empat & 20.836 & 20.438 & 41.274 \\
\hline 13 & Teluk Dalam & 9.105 & 8.952 & 18.057 \\
\hline 14 & Air Batu & 20.598 & 20.369 & 40.967 \\
\hline 15 & Sei Dadap & 16.336 & 15.929 & 32.265 \\
\hline 16 & Buntu Pane & 11.770 & 11.832 & 23.602 \\
\hline 17 & Tinggi Raja & 9.483 & 9.464 & 18.947 \\
\hline 18 & Setia Janji & 5.983 & 5.994 & 11.977 \\
\hline 19 & Meranti & 10.056 & 10.232 & 20.288 \\
\hline 20 & Pulo Bandring & 14.595 & 14.413 & 29.008 \\
\hline 21 & Rawang Panca Arga & 9.293 & 9.053 & 18.346 \\
\hline 22 & Air Joman & 24.165 & 23.802 & 47.967 \\
\hline 23 & Silo Laut & 10.552 & 10.524 & 21.076 \\
\hline 24 & Kisaran Barat & 28.611 & 29.383 & 57.994 \\
\hline 25 & Kisaran Timur & 35.679 & 36.588 & 72.267 \\
\hline & TOTAL & 351.415 & 348.305 & 699.720 \\
\hline
\end{tabular}

Sumber: Badan Pusat Statistik Kabupaten Asahan Tahun 2015.

\section{Penerapan BPHTB perolehan hak atas tanah dan/atau bangunan di Kabupaten Asahan}

Setiap manusia mempunyai kebutuhan pokok berupa tempat tinggal, maka hampir semua orang pernah atau akan melakukan transaksi pengalihan hak atas tanah dan atau bangunan. Apabila mendengar atau akan melakukan transaksi jual beli rumah, tentu menimbulkan pertanyaan tentang prosedur pengalihan hak atas tanah dan atau bangunan, misalnya terkait dengan transaksi pengalihan hak atas 
tanah dan bangunan yang dikenakan pajak, atau terkait dengan jumlah pajak yang harus dibayarkan kepada negara.

Sebelum keluarnya UU No. 21 tahun 1997, tidak ada dasar hukum yang jelas untuk pemungutan pajak atas pemindahan hak atas tanah dan atau bangunan, bahkan di dalam UU No. 5 Tahun 1950 yang menggantikan semua peraturan pertanahan di Indonesia, juga tidak ada mengatur pengenaan bea balik nama atas jual beli tanah dan atau bangunan. Sebelum berlakunya UU No. 5 Tahun 1960, maka setiap pemindahan hak atas harta tetap yang ada di wilayah Indonesia, dipungut Bea Balik Nama berdasarkan Ordonansi Bea Balik Nama Staatblad 1924 Nomor 291. Objek Bea Balik Nama (BBN) menurut ordonansi tersebut adalah pemindahan hak yang dilakukan dengan pembuatan akta berdasarkan Ordonansi Bea Balik Nama Staatblad 1834 Nomor 27.

Berlakunya UU No. 5 Tahun 1960, membawa konsekuensi, bahwa BBN atas harta tetap berupa tanah tidak dapat dilaksanakan, karena pungutan tersebut melekat ada hukum tanah berdasarkan Buku II Kitab Undang-undang Hukum Perdata, sedangkan ketentuan Buku II ini sepanjang yang mengenai bumi, air dan kekayaan alam yang terkandung di dalamnya telah dicabut oleh UU No. 5 Tahun 1960, akibatnya bahwa BBN atas tanah tidak dapat dipungut lagi, dan untuk menggantikan pungutan BBN atas harta tetap berupa tanah, maka Pemerintah bersama Dewan Perwakilan Rakyat (DPR) bersepakat untuk memberlakukan UU No. 21 Tahun 1997, yang sekaligus mencabut Ordonansi Bea Balik Nama Staatblad 1924 Nomor 291.

Awal berlakunya UU No. 21 Tahun 1997, keadaan perekonomian negara Indonesia sedang memerlukan pembenahan secara menyeluruh di segala sektor. Dengan pertimbanga usulan dari berbagai pihak terutama pihak-pihak yang mempunyai kepentingan dengan hal-hal yang berkaitan dengan tanah dan bangunan (seperti Real Estate Indonesia) ditambah lagi dengan keadaan perekonomian yang sedang kurang kondusif, maka UU No. 21 Tahun 1997 ditangguhkan pemberlakuannya selama 6 (enam) bulan berdasarkan Peraturan Perpu No. 1 Tahun 1997, yang ditetapkan pada tanggal 31 Desember 1997. 
Perpu No. 1 Tahun 1997 disetujui oleh DPR dan ditetapkan menjadi Undang-undang Nomor 1 Tahun 1998, dan dengan demikian maka pemberlakuan terhadap aturan tentang BPHTB, baru dapat berlaku efektif sejak tanggal 1 Juli 1998. Selanjutnya dengan diberlakukan pula Undang-undang Nomor 28 Tahun 2009 tentang Pajak Daerah dan Retribusi Daerah (UU No. 28 Tahun 2009), yang bertujuan untuk menyesuaikan kebijakan otonomi daerah, sebagaimana diatur dalam Undang-undang Nomor 32 Tahun 2004 tentang Pemerintahan Daerah (yang telah diubah beberapa kali, terakhir dengan dalam Undang-undang Nomor 12 Tahun 2008) dan Undang-undang Nomor 33 Tahun 2004 tentang Perimbangan Keuangan antara Pemerintah Pusat dan Pemerintahan Daerah.

Untuk melaksanakan ketentuan Pasal 2 ayat (2) huruf k UU No. 28 Tahun 2009, maka Pemerintah Daerah Kabupaten Asahan pada tanggal 16 Maret 2011 telah menetapkan Perda Nomor 3 Tahun 2011 sebagai payung hukum untuk melakukan pemungutan Bea Perolehan Hak Atas Tanah dan Bangunan di daerah Kabupaten Asahan. Bea perolehan hak atas tanah dan bangunan (BPHTB) adalah pajak yang dikenakan atas perolehan hak atas tanah dan/atau bangunan, yang selanjutnya disebut pajak (Siahaan 2003: 42). BPHTB pada dasarnya dikenakan atas setiap perolehan hak yang diterima oleh orang pribadi atau badan hukum yang terjadi dalam wilayah hukum Negara Indonesia, yang merupakan pajak terhutang dan harus dibayar oleh pihak yang memperoleh suatu hak atas tanah dan bangunan agar akta peralihan hak seperti jual beli, hibah, tukar menukar, atau risalah lelang, atau surat keputusan pemberian hak atas tanah dapat dibuat dan ditandatangani oleh pejabat yang berwenang.

Tujuan pembentukan undang-undang tentang BPHTB sebagai supaya kemandirian Bangsa Indonesia untuk memenuhi pengeluaran pemerintah berkaitan dengan tugasnya untuk menyelenggarakan Pemerintahan Umum dan Pembangunan Nasional. Berdasarkan Pasal 4 ayat (1) UU No. 21 Tahun 1997 ditentukan bahwa yang menjadi subyek pajak adalah orang pribadi atau badan yang memperoleh hak atas tanah dan atau bangunan (Grafika 2002: 82). Maksudnya bahwa pajak dikenakan kepada pihak yang memperoleh hak dari 
suatu peralihan hak atas tanah dan bangunan, sehingga orang atau pribadi atau badan hukum yang memperoleh hak atas tanah yang menjadi wajib pajak BPHTB.

Badan adalah sekumpulan orang dan atau modal yang merupakan kesatuan, baik yang melakukan usaha, maupun tidak melakukan usaha yang meliputi Perseroan Terbatas (PT), Perseroan Komanditer (CV), Perseroan lainnya, Badan Usaha Milik Negara atau Daerah dengan nama dan dalam bentuk apapun, Firma, Kongsi, Koperasi, Dana Pensiun, Persekutuan, Perkumpulan, Yayasan, Organisasi Sosial Politik, atau Organisasi yang sejenis, Lembaga, bentuk usaha tetap, dan bentuk badan lainnya (Siahaan 2003: 72).

Berdasarkan Pasal 2 ayat (3) Perda Kabupaten Asahan No. 3 Tahun 2011 ditentukan bahwa yang menjadi obyek pajak adalah perolehan hak atas tanah dan atau bangunan. Obyek perolehan pada BPHTB haruslah tanah dan/atau bangunan. Dengan demikian apabila obyek perolehan hak bukan tanah dan bangunan, misalnya jual beli saham suatu perusahaan yang memiliki kantor dan pabrik, maka perolehan hak yang terjadi bukan merupakan obyek BPHTB.

Perda Kabupaten Asahan tersebut mengatur bahwa perolehan hak atas tanah dan bangunan yang menjadi obyek pajak terjadi karena 2 (dua) hal, yaitu: (a) pemindahan hak; dan (b) pemberian hak baru. Pemindahan hak yang merupakan obyek BPHTB, meliputi 13 (tiga belas) jenis perolehan hak, yaitu:

a. Perolehan hak karena jual beli, yaitu perolehan hak atas tanah dan bangunan oleh pembeli dari penjual (pemilik tanah dan bangunan atau kuasanya) yang terjadi melalui transaksi jual beli, dimana atas perolehan tersebut pembeli menyerahkan sejumlah uang kepada penjual;

b. Perolehan hak karena tukar menukar, yaitu perolehan hak atas tanah dan bangunan yang diterima oleh seorang atau suatu badan hukum dari pihak lain dan sebagai gantinya orang atau badan hukum tersebut memberikan tanah dan bangunan miliknya kepada pihak lain tersebut sebagai pengganti tanah dan bangunan yang diterimanya;

c. Perolehan hak karena hibah, yaitu perolehan hak atas tanah dan bangunan yang diperoleh oleh seorang penerima hibah yang berasal dari pemberi hibah pada saat pemberi hibah masih hidup; 
d. Perolehan hak karena hibah wasiat, yaitu suatu penetapan wasiat yang khusus mengenai pemberian hak atas tanah dan atau bangunan kepada orang pribadi atau badan hukum tertentu, yang berlaku setelah pemberi hibah wasiat meninggal dunia;

e. Perolehan hak karena waris, yaitu perolehan hak atas tanah dan bangunan oleh ahli waris dari pewaris (pemilik tanah dan bangunan) yang berlaku setelah pewaris meninggal dunia;

f. Perolehan hak karena pemasukan dalam perseroan atau badan hukum lainnya, yaitu perolehan hak atas tanah dan bangunan sebagai hasil pengalihan hak atas tanah dan bangunan dari orang pribadi atau badan hukum kepada perseroan atau badan hukum lain;

g. Perolehan hak karena pemisahan hak yang mengakibatkan peralihan, yaitu perolehan hak atas tanah dan bangunan yang berasal dari pemindahan sebagian hak bersama atas tanah dan atau bangunan. oleh orang pribadi atau badan kepada sesama pemegang hak bersama;

h. Perolehan hak karena penunjukan pembeli dalam lelang, yaitu perolehan hak atas tanah dan bangunan oleh seorang atau suatu badan hukum yang ditetapkan sebagai pemenang lelang oleh pejabat lelang sebagaimana yang tercantum dalam risalah lelang. perolehan hak sebagai pelaksanaan putusan hakim yang mempunyai kekuatan hukum yang tetap yaitu terjadi dengan peralihan hak dari orang pribadi atau badan hukum sebagai pihak yang semula memiliki suatu tanah dan bangunan kepada pihak yang ditentukan dalam putusan hakim menjadi pemilik baru dari tanah dan bangunan tersebut;

i. Perolehan hak karena penggabungan usaha, yaitu perolehan hak atas tanah dan bangunan oleh badan usaha yang tetap berdiri dari badan usaha yang telah digabungkan ke dalam badan usaha yang tetap berdiri tersebut;

j. Perolehan hak karena peleburan usaha, yaitu perolehan hak atas tanah dan bangunan oleh badan usaha baru sebagai hasil dari peleburan usaha dari badan-badan usaha yang tergabung dan telah dilikuidasi; 
k. Perolehan hak karena pemekaran usaha, yaitu perolehan hak atas tanah dan bangunan oleh badan usaha yang baru didirikan yang berasal dari aktiva badan usaha induk yang dimekarkan; dan

1. Perolehan hak karena hadiah, yaitu perbuatan hukum berupa penyerahan hak atas tanah dan atau bangunan yang dilakukan oleh orang pribadi atau badan hukum kepada penerima hadiah.

Pemberian hak baru yang mengakibatkan perolehan hak atas tanah dan bangunan yang merupakan obyek BPHTB meliputi 2 (dua) jenis perolehan hak, yaitu:

a. Perolehan hak karena pemberian hak baru sebagai kelanjutan pelepasan hak, yaitu pemberian hak baru kepada orang pribadi atau badan hukum dari negara atas tanah yang berasal dari pelepasan hak; dan

b. Perolehan hak karena pemberian hak baru di luar pelepasan hakim yaitu pemberian hak baru atas tanah kepada orang pribadi atau badan hukum dari negara menurut peraturan perundang-undangan yang berlaku (PMNA/Kepala BPN Nomor 9 Tahun 1999 tentang Pemberian Hak Atas Tanah Negara).

Berdasarkan Perda Kabupaten Asahan No. 3 Tahun 2011, dapat diketahui bahwa setelah akta peralihan hak ditandatangani berarti sudah jelas pula obyek dari BPHTB yang dapat dialihkan. Untuk melakukan perhitungan pajak terutang, terlebih dahulu harus ditentukan nilai dari perolehan obyek pajak dan hal ini diatur dalam Pasal 4 ayat (1) dan (2) Perda Kabupaten Asahan No. 3 Tahun 2011, yang menentukan bahwa nilai perolehan obyek pajak meliputi:

a. jual beli adalah harga transaksi;

b. tukar menukar adalah nilai pasar;

c. hibah adalah nilai pasar

d. hibah wasiat adalah nilai pasar;

e. waris adalah nilai pasar;

f. pemasukan dalam perseroan atau badan hukum lainnya adalah nilai pasar;

g. pemisahan hak yang mengakibatkan peralihak hak adalah nilai pasar;

h. peralihan hak karena karena pelaksanaan putusan hakim yang mempunyai kekuatan hukum tetap adalah nilai pasar; 
i. pemberian hak baru atas tanah sebagai kelanjutan dari pelepasan hak adalah nilai pasar;

j. pemberian hak baru atas tanah di luar pelepasan hak adalah nilai pasar;

k. penggabungan usaha adalah nilai pasar;

1. peleburan usaha adalah nilai pasar;

m. pemekaran usaha adalah nilai pasar

n. hadiah adalah nilai pasar; dan/atau

o. penunjukan pembeli dalam lelang adalah harga transaksi yang tercantum dalam risalah lelang.

Selanjutnya dalam Pasal 4 ayat (3) Perda Kabupaten Asahan No. 3 Tahun 2011, ditentukan pula bahwa dalam hal nilai pasar lebih rendah dari pada nilai jual obyek pajak pajak bumi dan bangunan, maka nilai perolehan obyek pajak yang digunakan sebagai dasar pengenaan BPHTB adalah nilai jual obyek pajak pajak bumi dan bangunan pada tahun terjadinya perolehan. Apabila nilai perolehan obyek pajak dari terjadinya perolehan hak sudah jelas, maka untuk melakukan perhitungan selanjutnya adalah dengan mengetahui berapa nilai obyek pajak tidak kena pajak.

Ketentuan tentang nilai obyek pajak tidak kena pajak BPHTB dari harta diatur dalam Pasal 7 Perda Kabupaten Asahan No. 3 Tahun 2011 yang menentukan bahwa Nilai Obyek Pajak Tidak Kena Pajak (NOPTKP) ditetapkan secara regional paling banyak Rp. 60.000.000,00 (enam puluh juta rupiah), kecuali dalam hal perolehan hak karena waris, atau hibah wasiat yang diterima orang pribadi yang masih dalam hubungan keluarga sedarah dalam garis keturunan lurus satu derajat ke atas atau satu derajat ke bawah dengan pemberi hibah wasiat, termasuk suami/istri, Nilai Obyek Pajak Tidak Kena Pajak ditetapkan secara regional paling banyak Rp. 300.000.000,00 (tiga ratus juta rupiah). Untuk melakukan perhitungan BBHTB dari hibah wasiat yang harus dibayar, besarannya berdasarkan regulasi yang telah diatur dalam Pasal 5 Perda Kabupaten Asahan No. 3 Tahun 2011 yang menentukan bahwa tarif pajak ditetapkan sebesar 5\% (lima persen). Hal ini berarti ada pembedaan antara perolehan hak atas dengan wasiat dan lainnya. Besarnya BРHTB yang harus dibayar berdasarkan nilai 
perolehan obyek pajak dari perolehan hak tersebut setelah dikurang dengan Rp. 60.000.000.- (enam puluh juta rupiah), yaitu pengurangan dari Nilai Perolehan Objek Pajak Tidak Kena Pajak (NPOPTKP) kemudian dikalikan dengan 5\%. Khusus untuk hibah wasiat dikurangkan dengan Nilai Perolehan Objek Pajak Tidak Kena Pajak (NPOPTKP) sebesar Rp. 300.000 .000 (tiga ratus juta rupiah) dikalikan dengan $5 \%$.

Cara perhitungan sebagai contoh yang dapat diambil sebagai berikut: Tuan A hendak membeli sebidang tanah dari Tuan B. Jual beli tersebut hendak dibuat dalam akta jual beli di hadapan Pejabat Pembuat Akta Tanah (PPAT), bahwa sebelum Akta dibuat oleh PPAT, Tuan A harus terlebih dahulu membayar kewajibannya berupa pembayaran BPHTB. PPAT dilarang membuat akta jual beli tanah apabila belum dilakukan pelunasan BPHTB, misalnya tanah yang hendak dibeli dari Tuan B seluas $400 \mathrm{~m}^{2}$ dan berdiri bangunan di atasnya seluas $300 \mathrm{~m}^{2}$. Untuk mengetahui perhitungan BPHTB yang harus dibayarkan oleh Tuan A, maka terlebih dahulu dihitung NJOP (Nilai Jula Objek Pajak) dari tanah dan bangunan yang akan dijual, dan penentuan besar NJOP Jual beli adalah harga transaksi jual beli atau tidak boleh lebih rendah dari NJOP PBB. Besarnya kewajiban atas BPHTB dari jual beli tersebut adalah dengan langkah-langkah berikut:

a. Penetapan objek BPHTB

Dalam contoh kasus perhitungan BPHTB terhadap hak atas tanah dan bangunan yang diterima oleh Tuan A, maka penetapan atas hak atas tanah dan bangunan telah dilakukan dengan pembuatan akta jual belinya di hadapan PPAT, apabila kewajiban pembayar BPHTB telah lunas.

b. Penentuan nilai perolehan obyek pajak (NPOP) dari jual beli

Pada penerimaan hak atas tanah akibat jual beli tersebut, sesuai dengan akta jual beli, yaitu tanah seluas $400 \mathrm{~m}^{2}$ dan bangunan di atasnya seluas $300 \mathrm{~m}^{2}$. Sesuai Pasal 4 Perda Kabupaten Asahan No. 3 Tahun 2011, maka nilai perolehan obyek pajak didasarkan pada jual beli waktu didaftarkan peralihan haknya. Misalnya transaksi jual beli antara Tuan A dan Tuan B yang dipakai NJOP-nya berdasarkan transaksi jual beli atas tanah dan bangunan, yaitu 
sebesar Rp. 300.000.000.- (tiga ratus juta rupiah), maka nilai perolehan objek pajak dari jual beli adalah Rp. 300.000 .000 (tiga ratus lima puluh juta rupiah)

c. Penentuan nilai perolehan obyek pajak tidak kena pajak (NPOPTKP) dari jual beli

Berdasarkan Pasal 7 Perda Kabupaten Asahan No. 3 Tahun 2011, maka obyek pajak tidak kena pajak ditetapkan secara regional paling banyak Rp. 60.000.000,00 (enam puluh juta rupiah), kecuali dalam hal perolehan hak karena waris, atau hibah wasiat yang diterima orang pribadi yang masih dalam hubungan keluarga sedarah dalam garis keturunan lurus satu derajat ke atas atau satu derajat ke bawah dengan pemberi hibah wasiat, termasuk suami/istri, Nilai Obyek Pajak Tidak Kena Pajak ditetapkan secara regional paling banyak Rp. 300.000.000,00 (tiga ratus juta rupiah), dan karena dalam contoh kasus ini adalah jual beli, maka yang menjadi nilai obyek pajak tidak kena pajak adalah sebesar Rp. 60.000.000.- (enam puluh juta rupiah).

d. Penghitungan besarnya BPHTB dari jual beli yang harus dibayar

Berdasarkan perhitungan yang diuraikan di atas, maka besarnya BPHTB dari jual beli yang harus dibayar oleh Tuan A atas tanah $400 \mathrm{~m}^{2}$ dan bangunan 300 $\mathrm{m}^{2}$ adalah sebesar Rp. 300.0000.000,- Rp. 60.000.000,- $($ NJOPTKP $)=R p$. 240.000.000,- sehingga BPHTB terutang Tuan A adalah 5\% x Rp. 240.0000,berarti sebesar Rp. 12.000.000,- (dua belas juta rupiah). Setelah perhitungan BPHTB, maka Tuan A membayarkan kewajibannya kepada Dinas Pendapatan Pengelolaan Keuangan dan Asset (DPPKA) Kabupaten Asahan, dan setelah formulir pembayaran BPHTB divalidasi oleh DPPKA Kabupaten Asahan, maka PPAT dapat membuat akta jual beli yang dimohonkan kepadanya.

Berdasarkan Pasal 20 ayat (2) UU No. 21 Tahun 1997 jo Keputusan Menteri Keuangan Republik Indonesia No. 518/KMK.04/2000 dan Keputusan Direktur Jenderal Pajak No. KEP-221/Pj/2002 tanggal 8 Maret 2002), maka terhadap BPHTB yang telah ditetapkan, maka wajib pajak masih dapat mengajukan pengurangan terhadap BPHTB, yaitu dalam hal sebagai berikut: 
a. Kondisi tertentu wajib pajak yang ada hubungannya dengan objek pajak yaitu:

1) wajib pajak orang pribadi yang memperoleh hak baru melalui program pemerintah di bidang pertanahan tidak mempunyai kemampuan secara ekonomis;

2) wajib pajak badan yang memperoleh hak baru selain hak pengelolaan dan telah menguasai tanah dan/atau bangunan secara fisik lebih dari 20 tahun yang dibuktikan dengan surat pernyataan wajib pajak dan keterangan dari pejabat pemerintah daerah setempat;

3) wajib pajak orang pribadi yang memperoleh hak atas tanah dan atau bangunan rumah sederhana (RS), dan rumah susun sederhana serta rumah sangat sederhana (RSS) yang diperoleh langsung dari pengembang dan dibayar secara angsuran; atau

4) wajib pajak orang pribadi yang menerima hibah dari orang pribadi yang mempunyai hubungan keluarga sedarah dalam garis keturunan lurus satu derajat ke atas atau satu derajat ke bawah.

b. Kondisi Wajib Pajak yang ada hubungannya dengan sebab-sebab tertentu, yaitu:

1) wajib pajak yang memperoleh hak atas tanah melalui pembelian dari hasil ganti rugi pemerintah yang nilai ganti ruginya di bawah nilai jual objek pajak;

2) wajib pajak yang memperoleh hak atas tanah sebagai pengganti atas tanah yang dibebaskan oleh pemerintah untuk kepentingan umum yang memerlukan persyaratan khusus;

3) wajib pajak badan yang terkena dampak krisis ekonomi dan moneter yang berdampak luas pada kehidupan perekonomian nasional sehingga wajib pajak harus melakukan restrukturisasi usaha atau utang usaha sesuai dengan kebijaksanaan pemerintah;

4) wajib pajak Bank Mandiri yang memperoleh hak atas tanah yang berasal dari Bank Bumi Daya, Bank Dagang Negara, Bank Pembangunan Indonesia, dan Bank Ekspor Impor dalam rangkaian proses penggabungan usaha (merger); 
5) wajib pajak badan yang melakukan pembangunan usaha (merger) atau lepeburan usaha (konsolidasi) dengan atau terlebih dahulu mengadakan likuidasi dan telah memperoleh keputusan persetujuan penggunaan nilai buku dalam rangka penggaungan atau peleburan usaha dari Direktur Jenderal Pajak;

6) wajib pajak yang memperoleh hak atas tanah dan atau bangunan yang tidak berfungsi lagi seperti semula disebabkan bencana alam atau sebabsebab lainnya seperti kebakaran, banjir, tanah longsor, gempa bumi, gunung meletus, huru-hara yang terjadi dalam jangka waktu paling lama 3 (tiga) bulan sejak penandatanganan akta; atau

7) wajib pajak orang pribadi veteran, Pegawai Negeri Sipil (PNS), Tentara Nasional Indonesia (TNI), Polisi Republik Indonesia (Polri), Pensiunan PNS, Purnawirawan TNI, Purnawirawan Polri atau janda/dudanya yang memperoleh hak atas tanah dan atau bangunan rumah dinas pemerintah.

c. Tanah dan atau bangunan digunakan untuk kepentingan sosial atau pendidikan yang semata-mata tidak untuk mencari keuntungan antara lain untuk panti asuhan, panti jompo, rumah yatim piatu, sekolah yang tidak ditujukan mencari keuntungan, rumah sakit swasta milik institusi pelayanan sosial masyarakat.

\section{Simpulan dan Saran}

\section{Simpulan}

Pajak merupakan iuran wajib kepada negara yang dipungut berdasarkan kekuatan undang-undang, tanpa adanya kontraprestasi dari pemerintah dan digunakan untuk membiayai rumah tangga negara, yakni pengeluaran-pengeluaran yang bermanfaat bagi masyarakat luas. Pelaksanaan pemungutan pajak dapat diserahkan kepada daerah, dan oleh sebab itu Pemerintah Daerah Kabupaten Asahan menyikapinya dengan mengeluarkan Perda No. 3 Tahun 2011. Perda ini pada dasarnya mengatur tentang perolehan hak atas tanah dan bangunan yang menjadi obyek pajak yang terjadi karena pemindahan hak dan pemberian hak baru. 


\section{Saran}

PPAT dapat membuat akta jual beli tanah dan/atau yang dimohonkan kepadanya setelah formulir pembayaran BPHTB divalidasi oleh DPPKA, oleh sebab itu PPAT diharapkan dapat lebih maksimal dalam pelaksanaan pemungutan pajak karena adanya perolehan hak atas tanah dan bangunan yang menjadi obyek pajak. 


\section{DAFTAR PUSTAKA}

\section{Buku:}

Erli Suandi. 2002. Hukum Pajak. Jakarta: Salemba Empat.

Ismawan Indra. 2000. Memahami Reformasi Perpajakan, Jakarta: PT. Elex Media Komputindo.

Rimsky Judisseno. 1999. Pajak dan Strategi Bisnis, Suatu Tinjauan Tentang Kepastian Hukum dan Penerapan Akutansi di Indonesia, Jakarta: PT. Gramedia Pustaka Utama.

Rochmat Soemitro. 1979. Dasar-dasar Hukum Pajak dan Pajak Pendapatan. Bandung: PT. Eresco.

Rukiah Handoko. 2000. Pengantar Hukum Pajak. Buku A, Seri Buku Ajar. Jakarta.

Santoso Brotodiharjo, R. 2008, Pengantar Ilmu Hukum Pajak, Cetakan Ke 20, Bandung: PT. Refika Aditama.

Siahaan, Marihot Pahala. 2003. Bea Perolehan Hak Atas Tanah dan Bangunan Teori dan Praktik. Edisi I. Cetakan I. Jakarta: PT. Raja Grafindo.

Wirawan B. Ilyas dan Richard Burton. 2004. Hukum Pajak, Edisi Revisi, Jakarta: Salemba Empat.

\section{Internet:}

Badan Pusat Statistik Kabupaten Asahan. "Kependudukan". https://asahankab. bps.go id. diakses tanggal 25 Maret 2016.

Wikipedia. "Kabupaten Asahan". https://id.wikipedia.org. diakses tanggal 25 Maret 2016. 


\section{BIODATA PENULIS}

$\begin{array}{ll}\text { Nama } & : \text { Bahmid, S.H., M.Kn } \\ \text { Pekerjaan } & : \text { Dosen Fakultas Hukum Universitas Asahan } \\ \text { Jabatan } & : \text { Lektor } \\ \text { Nomor HP } & : \text { 085261396981 } \\ \text { E-mail } & : \text { bahmidpanjaitan@ yahoo.co.id } \\ \text { Alamat Kantor } & : \text { Jl. Jenderal Ahmad Yani, Kelurahan Kisaran Naga, Kecamatan } \\ & \text { Kisaran Timur }\end{array}$

